\title{
KONSEP DESAIN TAS MODULAR FOTOGRAFI DAN VIDEOGRAFI
}

\author{
Alief Thufail Mahendra \\ Mahasiswa Program Studi Desain Produk, Jurusan Desain, \\ Institut Teknologi Adhi Tama Surabaya \\ e-mail: thufailmah28@gmail.com \\ Choirul Anam \\ Staf Pengajar Program Studi Desain Produk, Jurusan Desain, \\ Institut Teknologi Adhi Tama Surabaya \\ e-mail: choirul.despro@itats.ac.id
}

\begin{abstract}
Abstrak
Fotografi dan Videografi merupakan kegiatan atau profesi yang berhubungan dengan makhluk hidup. Dapat dilakukan oleh semua orang dan dapat dijadikan sebagai hobi maupun sebagai profesi. Dari kegiatan tersebut terdapat sebuah benda yang menjadi faktor utama selain kamera maupun drone, yaitu tas. Tas menjadi faktor utama sebagai tempat penyimpanan peralatan kamera pada saat para fotografer dan videografer melakukan kegiatan. Untuk saat ini perkembangan tas sangat bervariasi mulai dari bentuk yang kecil hingga bentuk yang besar. Terdapat berbagai jenis tas kamera, yaitu tas ransel, tas selempang, hingga tas jenis koper. Untuk masalah penempatan masih banyak yang bisa dikembangkan dari segi peletakkan peralatan hingga sistem pada tas. Penelitian ini dilakukan melalui dua proses, yaitu data literartur dan data lapangan. Data literatur didapatkan melalui sumber dari internet ataupun buku yang berkaitan dengan dengan penelitian. Sedangkan untuk data lapangan didapatkan melalui hasil survey, wawancara, dan observasi dengan para fotografer dan videografer. Proses perancangan memiliki beberapa tahapan antara lain, tahap pengumpulan data, tahap analisis, dan kebutuhan desain. Tahap analisis menggunakan analisis kebutuhan desain yang meliputi peralatan yang dibutuhkan fotografer dan videografer. Dilanjutkan dengan analisis warna, analisis material, analisis bentuk, analisis ergonomi, analisis sistem, analisis kompetitor, dan analisis tambahan. Disimpulkan antara lain, penelitian ini dengan hasil akhir produk tas ransel (backpack) desain tas modular fotografi dan videografi ialah agar memudahkan para fotografer dan videografer pada saat membawa peralatan, dan termasuk sebagai inovasi terbaru.
\end{abstract}

Kata kunci : Tas ransel, Modular, Fotografi, Videografi 
Alief Thufail Mahendra, Choirul Anam, Konsep Desain Tas Modular Fotografi Dan

Vidoegrafi

\section{Abstract}

Photography and Videography are activities or professions related to living things. It can be done by everyone and can be used as a hobby or as a profession. From these activities there is an object becomes the main factor besides the camera or drone, namely the bag. Bags become the main factor as a place to store camera equipment when photographers and videographers do any activities. Nowadays the development of bags varies greatly from small to large shapes. There are various types of camera bags, namely backpacks, sling bags, to suitcase type bags. For the problem of placement, there is still much that can be developed in terms of laying equipment to the system in the bag. This research was conducted through two processes, namely literary data and field data. Literature data are obtained through sources from the internet or books related to research. As for the field data, were obtained through the results of surveys, interviews, and observations with photographers and videographers. The design process has several stages including, the data collection stage, the analysis phase, and the design requirements. The analysis phase uses an analysis of design requirements which includes equipment needed by photographers and videographers. Followed by color analysis, material analysis, shape analysis, ergonomics analysis, system analysis, competitor analysis, and additional analysis. It was concluded among other things, this study with the final product of a backpack design of modular photography and videography bags is to make it easier for photographers and videographers when carrying equipment, and included as the latest innovations.

Keywords : Backpack, Modular, Photography, Videography

\section{Latar Belakang}

Fotografi merupakan kegiatan atau proses untuk menghasilkan seni gambar berupa foto dengan memanfaatkan media cahaya melalui sebuah alat yang dinamakan kamera dengan maksud dan tujuan tertentu. Pengertian fotografi sendiri lebih cenderung pada aktivitas atau proses memotretnya. Sedangkan, fotografer merupakan orang yang melakukan kegiatan tersebut (fotografi). Fotografer adalah sebuah profesi atau bisa dikatakan orang yang hidup dengan fotografi. Sementara itu, videografer bekerja sebagai bagian dari tim produksi yang menciptakan produk video. Seorang videografer memiliki tugas untuk mengkonsepkan, melakukan pengambilan video, dan menyunting video untuk keperluan promosi dan sosial media. Konsep video yang dibuat harus sesuai dengan permintaan dari kliennya. Hal tersebut dapat dicapai apabila seorang videografer juga menguasai perangkat lunak komputer untuk pengeditan video serta memiliki kreatifitas yang tinggi. Pada pengamatan peneliti, peralatan yang 60 dibutuhkan sebagai profesi fotografer dan videografer hampir mempunyai kesamaan peralatan utama yaitu kamera dan kamera drone. Beserta peralatan lainnya seperti lensa, tripod, microphone, memori dan baterai cadangan. Sementara itu, fotografer dan videografer membutuhkan tas untuk menampung dari berbagai peralatan yang dibutuhkan. Terdapat permasalahan lain yaitu untuk saat ini fotografer dan videografer harus mempunyai 2 jenis tas yang berbeda, sehingga fotografer dan videografer dapat menampung peralatan tersebut. Berdasarkan permasalahan tersebut, penelitian ini mempunyai solusi yaitu desain tas modular fotografi dan videografi. Sehingga para fotografer dan videografer tidak memerlukan 2 tas untuk menampung berbagai peralatan yang dibutuhkan. Tas modular fotografi dan videografi lebih efisien dan sangat dibutuhkan oleh para fotografer dan videografer. 


\section{Tujuan Perancangan}

Pada penelitian ini menggunakan judul "Desain Tas Modular Fotografi dan Videografi". Dengan rincian sebagai berikut:

\subsection{Kajian Tema}

Penelitian ini menggunakan tema Desain dan Permasalahan Sosial Gaya Hidup, dengan mengusung permasalahan pada saat ini yang di alami oleh para fotografer dan videografer yang masih mengalami permasalahan pada saat membawa peralatan.

\subsection{Desain}

Desain adalah kegiatan pemecahan masalah atau inovasi teknologis yang bertujuan untuk mencari solusi terbaik (sistem, proses, konfigurasi fisikal) dengan jalan memformulasikan terlebih dahulu gagasan inovatif tersebut ke dalam suatu model dan kemudian merealisasikan kenyataan secara kreatif.

\subsection{Tas (kamera)}

Tas kamera berfungsi untuk melindungi kamera dan menambah nilai estetika. Tas kamera SLR/DSLR umumnya berukuran besar, selain karena ukuran kamera yang mempunyai ukuran lebih besar, juga karena pada umumnya tas SLR/DSLR di desain untuk menyimpan beberapa lensa beserta aksesoris sekaligus. Tas kamera saku, sesuai dengan ukuran kamera, mempunyai ukuran yang relatif kecil, tidak terlalu berbeda dengan ukuran tas handphone.

\subsection{Modular}

Arti dari kata modular adalah memiliki kemampuan untuk dipindahkan dengan mudah dan umumnya berdiri sendiri dalam bentuk modul yang dapat dipisahpisahkan. Menurut The Free Dictionary, arti kata modular adalah sebuah komponen atau konstruksi yang distandarkan, seringkali dapat ditukar-tukar dalam proses pemasangannya yang dirancang untuk mempermudah perakitan ataupun penggunaan yang fleksibel.

\subsection{Fotografi}

Fotografi merupakan proses pembuatan gambar dengan menggunakan media cahaya, sehingga cahaya merupakan faktor utama dari perancangan ini. Secara umum fotografi memiliki arti yaitu proses atau sebuah metode untuk menghasilkan sebuah gambar/foto dari sebuah objek dengan menangkap dari pantulan cahaya yang mengenai objek tersebut kepada suatu media yang peka terhadap cahaya.

\subsection{Videografi}

Videografi adalah proses menggunakan media untuk merekam suatu moment/ kejadian yang dirangkum dalam sebuah sajian gambar dan suara yang dapat kita nikmati dikemudian hari baik sebagai sebuah kenangan ataupun sebagai bahan kajian untuk mempelajari apa yang sudah/pernah terjadi.

\section{Metode Perancangan}

Metode penelitian ini menggunakan metode penelitian kombinasi (Mixed Methods). Menurut Sugiyono (2011:404) bahwa, Metode penelitian kombinasi (mixed methods) adalah suatu metode penelitian yang mengkombinasikan atau menggabungkan antara metode kuantitatif dan metode kualitatif untuk digunakan secara bersama-sama dalam suatu kegiatan penelitian sehingga diperoleh data yang lebih komprehensif, valid, reliabel dan objektif.

Tujuan pendekatan dalam penelitian ini adalah meneliti permasalahan yang dialami oleh para fotografer dan videografer. Peneliti menggunakan metode survey dengan observasi dan melakukan kuisioner mengenai solusi terbaru yaitu Tas Modular Fotografer dan Videografer.

Setelah mendapatkan data dari hasil kuisioner maka data tersebut ditarik dipresentasekan untuk mengetahui jawaban tertinggi yang dipilih responden. Dan data tersebut dengan data wawancara, observasi, dan survey untuk memperkuat data. Kemudian data tersebut dianalisis dan menjadi fokus penelitian. 


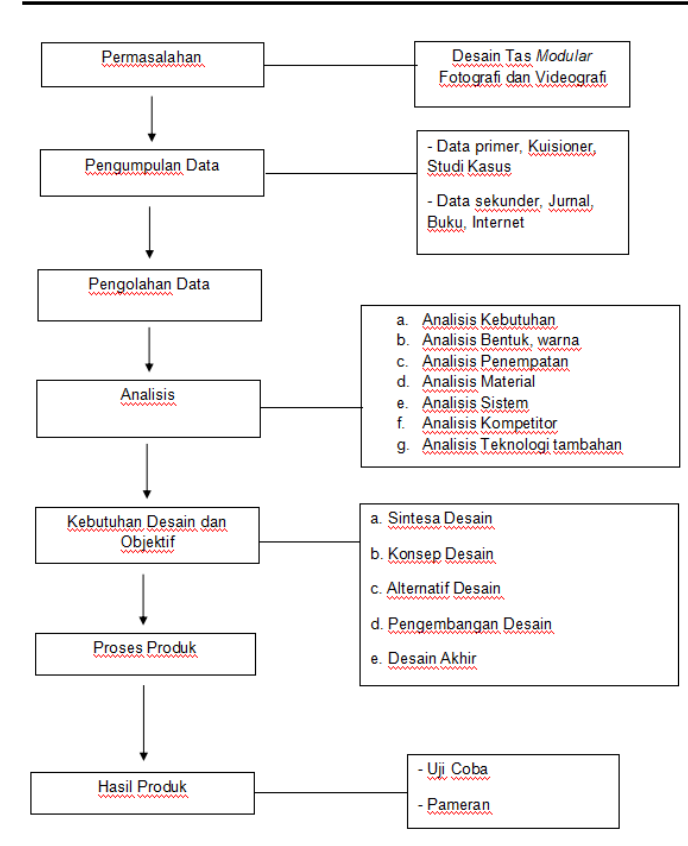

Gambar 1. Skema Penelitian

\section{Hasil dan Pembahasan \\ 4.1. Studi Kasus}

Studi Kasus dilakukan pada orang yang memiliki profesi atau ahli di bidang fotografi dan videografi. Pada penelitian ini membutuhkan informasi tas yang digunakan, serta barang-barang yang dibutuhkan oleh fotografer dan videografer ketika membawa tas tersebut. Peneliti telah berdiskusi dengan beberapa agensi-agensi yang menaungi fotografer dan videografer untuk membahas solusi terbaru dari peneliti, yaitu Tas Modular Fotografi dan Videografi.

\subsubsection{Zetizen Jawapos}

Zetizen adalah sebuah platform anak muda yang kreatif dan kekinian abis. Ada halaman di koran, situs di internet, media sosial, hingga berbagai rangkaian kegiatan. Hasil wawancara tersebut mengenai jenis tas serta alat yang dibutuhkan oleh fotografer dan videografer dari Zetizen. Untuk jenis tas menggunakan tas ransel dan tas selempang kamera pada umumnya, saat ini menggunakan lebih dari satu tas untuk membawa peralatan yang dibutuhkan, serta untuk aerial fotografi dan videografi meng62 gunakan drone mavic sebagai alat untuk mengambil objek.

\subsubsection{Cinetic Official}

Cinetic Official bergerak dibidang videografi wedding dan juga fotografi dalam acara wedding, gathering, dll. Mereka memulai produksi fotografi dan videografi pada tahun 2016. Pada tanggal 10 november 2019, peneliti menemui salah satu anggota dari cinetic official. Hasil wawancara tersebut mengenai jenis tas serta alat yang dibutuhkan oleh fotografer dan videografer dari cinetic official. Untuk jenis tas menggunakan tas ransel kamera pada umumnya, saat ini menggunakan lebih dari satu tas untuk membawa peralatan yang dibutuhkan, serta untuk aerial fotografi dan videografi menggunakan drone mavic sebagai alat untuk mengambil objek.

\subsubsection{Mikr Production Gang}

Mikr Production Gang bergerak dibidang videografi acara wedding, gathering, dll. Pada tanggal 13 desember 2019, peneliti menemui salah satu anggota dari Mikr Production Gang bagian videografi. Membahas tentang solusi terbaru oleh peneliti mengenai tas yang digunakan para fotografer dan videografer. Peralatan yang dibutuhkan yaitu kamera lumix g-85, lensa lumix $42 \mathrm{~mm}$, tripod, charger kamera, drone mavic pro 2. Hasil wawancara tersebut mengenai jenis tas serta alat yang dibutuhkan oleh videografer. Untuk jenis tas menggunakan tas ransel dan tas selempang kamera pada umumnya, saat ini menggunakan lebih dari satu tas untuk membawa peralatan yang dibutuhkan, serta untuk aerial fotografi dan videografi menggunakan drone mavic dan phantom sebagai alat untuk mengambil objek.

\subsection{Studi Kebutuhan}

Dalam studi kebutuhan berikut, peneliti melakukan pengamatan dari hasil studi kasus observasi tentang kebutuhan para fotografer dan videografer. Dari kegiatan 
Vol. 7, No. 2, April 2020

observasi yang dilakukan didapatkan jenis peralatan yang dibutuhkan oleh fotografer sebagai berikut :

\section{Zetizen Jawapos}

1. Satrio (Videografer)

Berdasarkan hasil wawancara dengan

Satrio yang dilakukan pada tanggal pada tanggal 12 desember 2019 membahas apa saja yang dibutuhkan pada saat liputan kerja. Satrio membawa beberapa peralatan yang dibutuhkan, yaitu kamera canon 600-d, kamera canon 60-d, lensa $18-135 \mathrm{~mm}$, lensa $18-50 \mathrm{~mm}$, tripod, charger baterai, set drone spark.

\section{Prayoga (Fotografer)}

Berdasarkan hasil wawancara dengan Prayoga yang dilakukan pada tanggal pada tanggal 12 desember 2019 membahas apa saja yang dibutuhkan pada saat liputan kerja. Prayoga membawa beberapa peralatan yang dibutuhkan, yaitu kamera canon 80-d, lensa 17 $40 \mathrm{~mm}$, tripod, charger baterai.

3. Jefri (Fotografer)

Berdasarkan hasil wawancara dengan Prayoga yang dilakukan pada tanggal pada tanggal 12 desember 2019 membahas apa saja yang dibutuhkan pada saat liputan kerja. Jefri membawa beberapa peralatan yang dibutuhkan, yaitu kamera canon 80-d, lensa 18 $55 \mathrm{~mm}$, lensa $50 \mathrm{~mm}$, lensa $70-200$, tripod, charger baterai, flash external.

\section{Cinetic Official}

Berdasarkan hasil wawancara dengan narasumber yang berprofesi sebagai videografer di Agensi tersebut. Selain seorang videografer, profesi tambahannya yaitu sebagai fotografer. Narasumber itu bernama Bayu Sepsterian yang dilakukan pada tanggal pada tanggal 10 november 2019 membahas apa saja yang dibutuhkan pada saat liputan kerja. Bayu membawa beberapa peralatan yang dibutuhkan, yaitu kamera sony mirrorless a-6300, sony mirrorless a-6000, minolta $50 \mathrm{~mm}$, tripod, charger baterai, drone mavic pro 2 , stabilizer zhiyun crane.

\section{Mikr Production Gang}

Berdasarkan hasil wawancara dengan salah satu narasumber yang berprofesi sebagai videografer dan juga selaku owner dari agensi Mikr Production Gang yang bernama Brillyan Anugrah yang dilakukan pada tanggal pada tanggal 13 desember 2019 membahas apa saja yang dibutuhkan pada saat liputan kerja. Brillyan membawa beberapa peralatan yang dibutuhkan, yaitu kamera lumix g-85, lensa lumix $42 \mathrm{~mm}$, tripod, charger kamera, drone mavic pro 2.

\subsection{Analisis Kebutuhan}

Sebelum mendesain tas modular fotografi dan videografi, peneliti melakukan wawancara kepada narasumber untuk mengetahui kebutuhan narasumber pada saat melakukan kegiatan liputan. Berikut hasil yang didapat dari wawancara yang dilakukan kepada 3 tempat studi kasus berdasarkan kebutuhan masing-masing narasumber.

\subsubsection{Hasil Wawancara}

Berikut hasil wawancara kepada 3 tempat studi kasus mengenai perlengkapan yang dibutuhkan oleh fotografer dan videografer. 
Alief Thufail Mahendra, Choirul Anam, Konsep Desain Tas Modular Fotografi Dan Vidoegrafi

Tabel 1.

\begin{tabular}{|c|c|c|c|c|}
\hline No & Nama & Kebutuhan & Jumlnh & Jenis. \\
\hline \multirow[t]{5}{*}{1} & \multirow[t]{5}{*}{ Sasio } & Kamera & 2 & $\begin{array}{ll} & \text { Cano } \\
\text { y } 60 D \\
\text { - Cano } \\
\text { n } \\
\text { 600D }\end{array}$ \\
\hline & & Leasz. & 2 & $\begin{array}{l}\text { - Lensa } \\
13- \\
135 \mathrm{~m} \\
\mathrm{~m} \\
\bullet \quad \text { Lensa } \\
13- \\
50 \mathrm{~mm}\end{array}$ \\
\hline & & Tripod & 1 & $\begin{array}{l}\text { Tripod } \\
\text { lapera }\end{array}$ \\
\hline & & $\begin{array}{l}\text { Charger } \\
\text { Batergi. }\end{array}$ & 1 & $\begin{array}{l}\text { Charger } \\
\text { batergi } \\
\text { can on }\end{array}$ \\
\hline & & Drans & 1 & DJI Spark \\
\hline \multirow[t]{4}{*}{2} & \multirow[t]{4}{*}{$\begin{array}{l}\text { Pravpg } \\
\text { a }\end{array}$} & Kamera & 1 & Canon SOD \\
\hline & & Lensz. & 1 & $\begin{array}{l}\text { Lensa } \\
40 \mathrm{mina}\end{array}$ \\
\hline & & $T$ Trood & 1 & $\begin{array}{l}\text { Trtpod } \\
\text { barefe } \\
\text { DSLR }\end{array}$ \\
\hline & & $\begin{array}{l}\text { Chargar } \\
\text { Batergi }\end{array}$ & 1 & $\begin{array}{l}\text { Charger } \\
\text { baterai } \\
\text { cavon }\end{array}$ \\
\hline \multirow[t]{5}{*}{3} & \multirow[t]{5}{*}{ Jefri } & Kamera & 1 & Canon 8-D \\
\hline & & Lem:a & 3 & 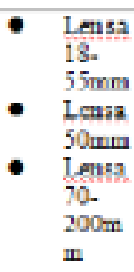 \\
\hline & & Iripod & 1 & $\begin{array}{l}\text { Triquod } \\
\text { bapese }\end{array}$ \\
\hline & & $\begin{array}{l}\text { Charger } \\
\text { Baterui }\end{array}$ & T & $\begin{array}{l}\text { Charger } \\
\text { baterai } \\
\text { cagon }\end{array}$ \\
\hline & & Flashin & 1 & $\begin{array}{l}\text { Flash } \\
\text { Extornal }\end{array}$ \\
\hline
\end{tabular}

Tabel 2.

\begin{tabular}{|c|c|c|c|c|}
\hline No & Nama & Kebutuhan & Jumlah & Jenis \\
\hline \multirow[t]{6}{*}{1} & \multirow[t]{6}{*}{$\begin{array}{l}\text { Bayu } \\
\text { Sepste } \\
\text { rian }\end{array}$} & Kamera & 2 & $\begin{array}{ll}- & \begin{array}{l}\text { Sony } \\
\text { mirrorles } \\
\\
\text { s A-6300 }\end{array} \\
- & \text { Sony } \\
\text { mirrorles } \\
\text { s a- } 6000\end{array}$ \\
\hline & & Lensa & 1 & $\begin{array}{l}\text { Lensa minolta } \\
50 \mathrm{~mm}\end{array}$ \\
\hline & & Tripod & 1 & Tripod kamera \\
\hline & & $\begin{array}{c}\text { Charger } \\
\text { Baterai }\end{array}$ & 1 & $\begin{array}{l}\text { Charger baterai } \\
\text { mirrorless }\end{array}$ \\
\hline & & Drone & 1 & DЛ Mavic pro 2 \\
\hline & & Stabilizer & 1 & Zhiyum Crane \\
\hline
\end{tabular}

3. Mikr Production Gang

Tabel 3 .

\begin{tabular}{|c|c|c|c|l|}
\hline No & Nama & Kebutuhan & Jumlah & \multicolumn{1}{|c|}{ Jenis } \\
\hline 1 & $\begin{array}{c}\text { Brillyan } \\
\text { Anugrah }\end{array}$ & Kamera & 1 & Lumix G85 \\
\cline { 3 - 5 } & Lensa & 1 & $\begin{array}{l}\text { Lensa lumix } \\
42 \mathrm{~mm}\end{array}$ \\
\cline { 4 - 5 } & & 1 & Tripod kamera \\
\cline { 3 - 5 } & & $\begin{array}{c}\text { Tripod } \\
\text { Baterai }\end{array}$ & 1 & $\begin{array}{l}\text { Charger baterai } \\
\text { lumix }\end{array}$ \\
\cline { 3 - 5 } & & Drone & 1 & DJI Mavic pro 2 \\
\cline { 3 - 5 } & & \multicolumn{2}{|c}{} \\
\hline
\end{tabular}


4.3. Alternatif Desain

1. Alternatif Desain 1
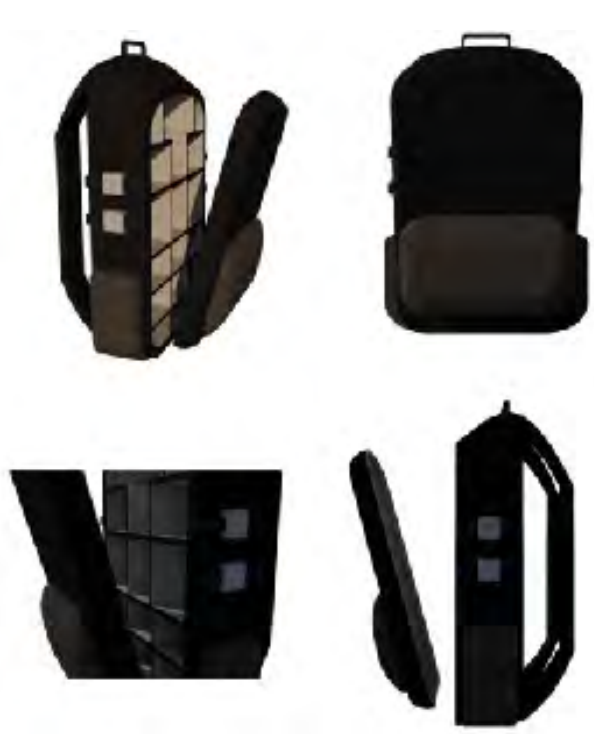

Gambar 2. Alternatif Desain 1

\section{Alternatif Desain 2}
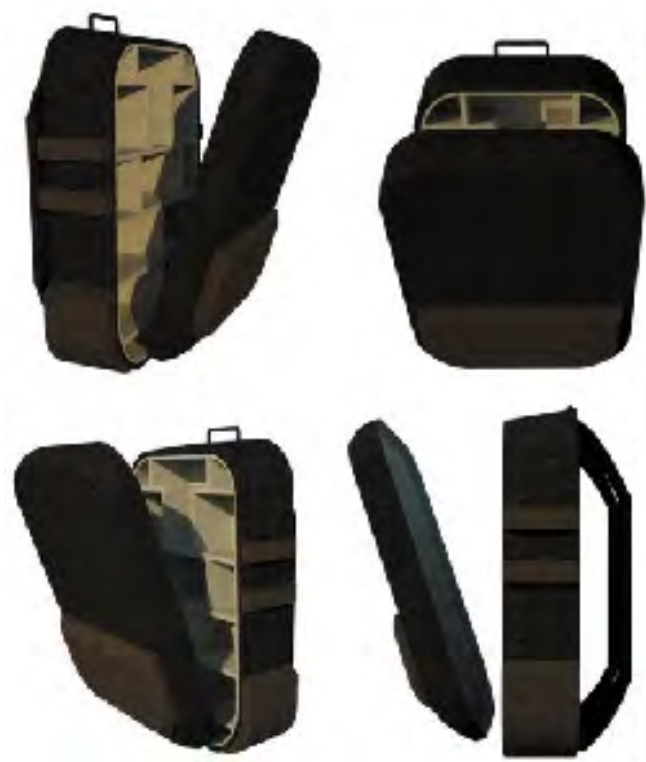

Gambar 3. Alternatif Desain 2
3. Alternatif Desain 3
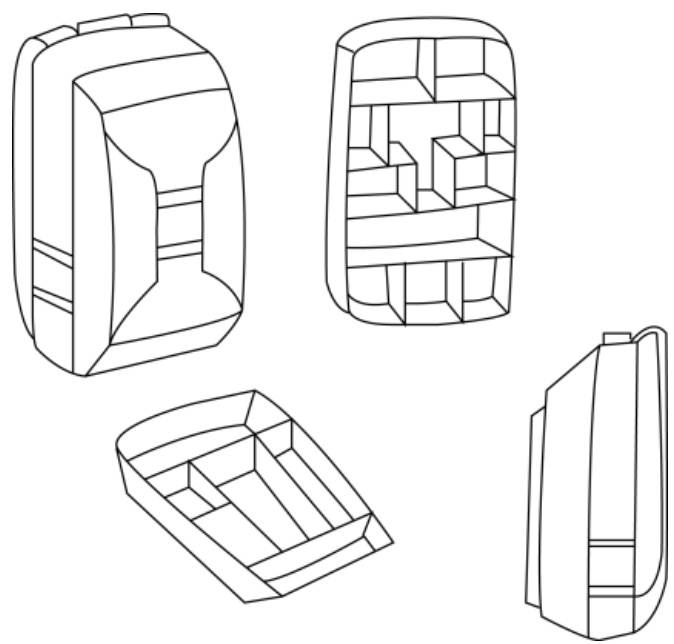

Gambar 4. Alternatif Desain 3

\section{Alternatif Desain 4}
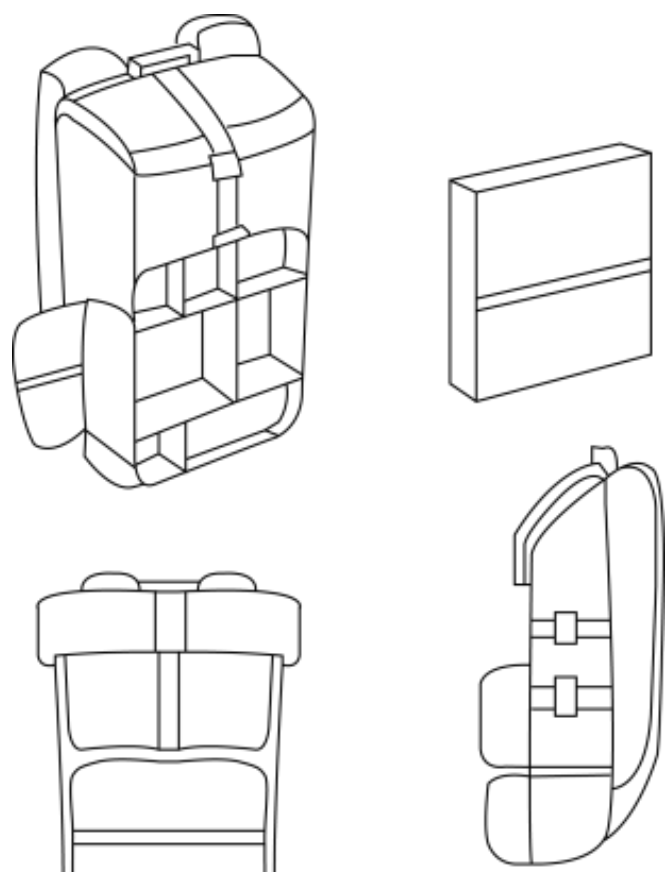

Gambar 5. Alternatif Desain 4 
Alief Thufail Mahendra, Choirul Anam, Konsep Desain Tas Modular Fotografi Dan

Vidoegrafi

\section{Alternatif Desain 5}
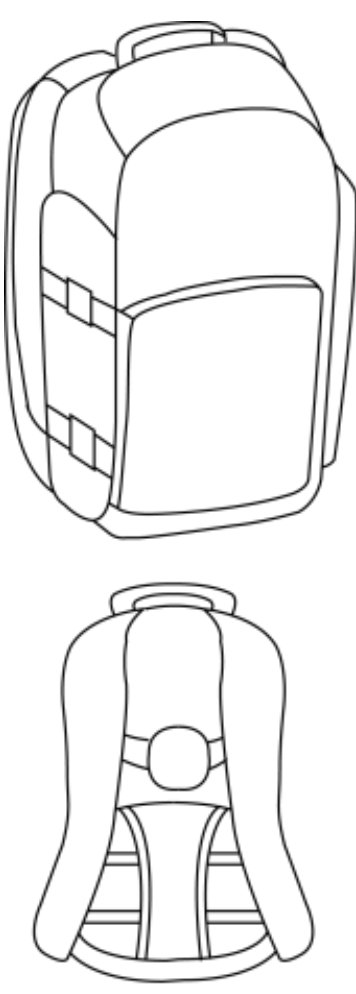
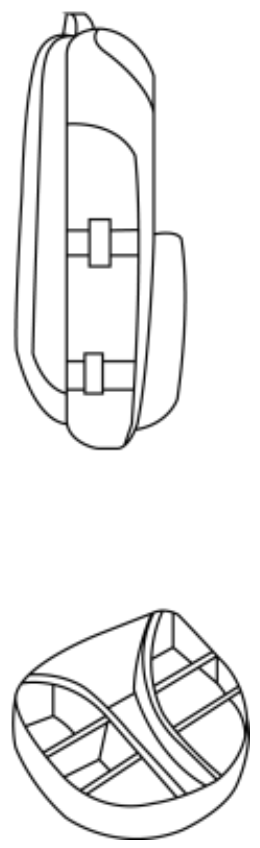

Gambar 6. Alternatif Desain 5

\section{Kesimpulan dan Saran}

\subsection{Kesimpulan}

Desain tas modular fotografi dan videografi merupakan inovasi terbaru yang menjawab permasalahan dari para fotografer dan videografer. Karena tidak perlu membawa lebih dari dua tas untuk membawa peralatan yang dibutuhkan. Pada tas ini mencakup dari kebutuhan yang ada mulai dari set kamera hingga drone.

\subsection{Saran}

Penelitian ini masih memiliki banyak kekurangan dan evaluasi, selain terkendala waktu dari narasumber yang sering berbenturan. Hingga dimensi pada tas yang akan digunakan. Maka dari itu peneliti harus menentukan dimensi ukuran tas yang tepat, sehingga dapat mencakup dari kebutuhan para fotografer dan videografer. 
Vol. 7, No. 2, April 2020

\section{Daftar Pustaka}

Nora Yuanita Restantin, Mirwan Ushada, Makhmudun Ainuri. 2012. "Desain Prototipe Meja dan Kursi Pantai Portabel dengan Integrasi Pendekatan Ergonomi, Value Engineering dan Kansei Engineering”.

Pricillia Eka Cristi, Yusita Kusumarini. 2014. "Perancangan Interior Modular pada Residential Space Tipe Studio". Program Studi Desain Interior, Universitas Kristen Petra. Jurnal Intra Vol. 2, No. 2.

Stanley Abednego. 2018. "Perancangan Interior One Stop Creative Photo Video Studio di Surabaya”. Program Studi Desain Interior, Universitas Kristen Petra. Jurnal Intra Vol. 6, No.2.

Heri Iswandi. 2018. "Peran dan Pengaruh Tampilan Desain pada Periklanan". Program Studi Desain Komunikasi Visual Universitas Indo Global Mandiri. JURNAL SENI DESAIN DAN BUDAYA VOLUME No. 3. 